\title{
Odrębność Niemiec Wschodnich w świetle koncepcji długiego trwania
}

\begin{abstract}
Zarys treści: W 1990 roku nastąpiło zjednoczenie Niemiec. Różnice pomiędzy mieszkańcami starych i nowych krajów związkowych, podobnie jak odrębności innych regionów (np. Bawaria), stały się stałym elementem debaty publicznej i analiz badawczych. Powstanie szczególnych cech Niemiec Wschodnich tłumaczone jest najczęściej 45-letnim funkcjonowaniem systemu socjalistycznego. W nawiązaniu do koncepcji długiego trwania (longue durée), nie można jednak odrzucić możliwości oddziaływania znaczenia wcześniejszych uwarunkowań. Kształtowana od wieków odrębność niemieckiego Wschodu (Slavia Germanica, Ostelbien) była czymś realnym. Obserwowano to w różnych sferach rzeczywistości: osadnictwie, gospodarce, języku, rozwiązaniach prawno-ustrojowych. Połączenie wcześniejszych uwarunkowań z rozwiązaniami wprowadzanymi przez komunistów mogło natomiast dodatkowo wzmocnić odrębne cechy niemieckiego Wschodu względem regionów zachodnioniemieckich.
\end{abstract}

Słowa kluczowe: Slavia Germanica, Ostelbien, Niemcy Wschodnie, długie trwanie.

\section{Wprowadzenie}

W 1990 roku nastąpiło zjednoczenie państw niemieckich. Od tego momentu zauważalne są istotne różnice pomiędzy mieszkańcami starych i nowych krajów związkowych. Pojawienie się tych odmienności tłumaczone jest najczęściej 45. latami istnienia dwóch państw niemieckich, z których każde funkcjonowało w innym systemie politycznym i społeczno-gospodarczym. Zdaniem komentatorów, to właśnie cechy uformowane w okresie podziału Niemiec miały być przyczyną problemów z unifikacją społeczeństwa zjednoczonego państwa i pojawiania się rozróżnienia Niemców na tzw. Ossie (Niemców ze wschodu) i Wessie (Niemców z zachodu). Niemcy ze wschodu uważali się za skromnych, podczas gdy Niemców z zachodu postrzegali jako aroganckich. W stosunku do zachodnich współrodaków mieli być także bardziej zdyscyplinowani, ale jednocześnie subtelniejsi. Niemcy z zachodu mieli cieszyć się przede wszystkim z rzeczy materialnych, podczas gdy mieszkańcy wschodu jako główny powód zadowolenia wymieniali relacje rodzinne i towarzyskie. Dawni obywatele NRD na przywitanie tradycyjnie uściskali dłonie, co mieszkańcy zachodu postrzegali to jako zbyt natrętne 
i staromodne. Mieszkańcy RFN byli znacznie bardziej zadowoleni ze swojego życia niż mieszkańcy NRD, zwłaszcza jeśli chodzi o pracę i dochody, ale także zdrowie i spędzanie wolnego czasu. $Z$ drugiej strony w Niemczech Zachodnich częściej diagnozowano uzależnienia, depresję, fobie społeczne i zaburzenia odżywiania, choć zdaniem ekspertów tylko dlatego, że Niemcy z Zachodu chętniej rozmawiali o swoich problemach (Jiménez 2015).

Różnice znajdują swoje odzwierciedlenie także w geografii wyborczej. W landach wschodnich, na tle zachodnich, znacznie słabiej wypadają tradycyjne i umiarkowane partie polityczne (CDU, SPD, FDP, Grüne), znacznie lepiej partie skrajne, czy to wywodząca się ze wschodnioniemieckiej lewicy Die Linke czy też nowi populistyczni nacjonaliści (AfD). Na wschodzie obserwowana jest też niższa frekwencja wyborcza (tab. 1).

Tabela 1. Wyniki wyborów do Bundestagu w 2017 roku (Erststimmen) w landach zachodnich i wschodnich

\begin{tabular}{lcccccccc}
\hline Region & $\begin{array}{c}\text { Fre- } \\
\text { kwen- } \\
\text { cja }\end{array}$ & $\begin{array}{c}\text { CDU/ } \\
\text { CSU }\end{array}$ & SPD & AfD & FDP & Linke & Grüne & $\begin{array}{c}\text { Pozo- } \\
\text { stali }\end{array}$ \\
\hline $\begin{array}{l}\text { Landy } \\
\text { zachodnie }\end{array}$ & 76,9 & 39,1 & 26,6 & 9,5 & 7,3 & 6,1 & 8,6 & 2,8 \\
\hline $\begin{array}{l}\text { Landy } \\
\text { wschodnie }\end{array}$ & 73,5 & 29,9 & 16,7 & 19,4 & 5,8 & 18,3 & 5,7 & 4,1 \\
\hline
\end{tabular}

Źródło: oprac. własne na podstawie Bundestagswahl 2017, https://www.bundeswahlleiter. de/bundestagswahlen/2017/ergebnisse.html

Nie negując znaczenia powojennego podziału kraju dla formowania się dzisiejszych podziałów, należy zauważyć, że już przed 1945 rokiem zwracano uwagę na odmienne cechy Niemiec wschodnich (np. Thalheim, Ziegfeld 1936). Dlatego również teraz pojawiają się głosy, że źródeł różnic pomiędzy landami wschodnimi i zachodnimi należy szukać we wcześniejszych uwarunkowaniach (von Wedel 2011; Kowalski 2013; Hawes 2018). W wielu wypadkach tropy prowadzą do bardzo odległej przeszłości. Wydaje się więc, że przy rozważaniach natury dzisiejszych podziałów w obrębie Niemiec, nie powinno się ograniczać jedynie do 45-letniego podziału w okresie 1945-1990.

Ta propozycja nawiązywałaby do koncepcji Fernanda Braudela, postulującej rozpatrywanie zjawisk i procesów społeczno-gospodarczych w perspektywie długiego trwania (longue durée), rozumianego jako czas długotrwałych i powolnych przemian kulturowych oraz cywilizacyjnych, niedostrzegalnych z perspektywy pojedynczego człowieka (Braudel 1982). Z tego powodu głównym zadaniem badacza reprezentującego nauki społeczne nie może być - najbardziej nawet skrupulatna, rzetelna i wyczerpująca - rejestracja faktów. Powinno się raczej 
opisywać struktury i instytucje opierające się w znacznym stopniu fluktuacjom historycznym i rzutujące na współczesne przeobrażenia. Sam F. Braudel analizując proces powstawania względnie zintegrowanej Europy odwoływał się np. do wydarzeń, instytucji i struktur z „długiego wieku XVI” (1450-1640) (Szczepański 1999).

Z tej perspektywy warto się przyjrzeć różnym elementom rzeczywistości mogącym wskazywać na bardzo odległe w czasie podłoże różnic między wschodnimi i zachodnimi niemieckimi społecznościami regionalnymi.

\section{Geneza niemieckiego Wschodu}

We wczesnym średniowieczu ziemie późniejszych Niemiec Wschodnich zamieszkiwały plemiona słowiańskie. Ich zachodni zasięg pokrywał się z linią rzeki Łaby i jej dopływu Soławy, w niektórych miejscach nawet ją przekraczając. W oparciu o tę linię monarchia frankońska ustanowiła swoją strefę pograniczną określaną mianem Limes Sorabicus. Ta pierwotna linia graniczna została w późniejszych stuleciach przełamana od zachodu, pod wpływem tzw. kolonizacji niemieckiej oraz politycznej ekspansji niemieckich ośrodków władzy. Zwraca się również uwagę na napływ słowiańskich osadników do sąsiedniej Turyngii (Strzelczyk 1974, 1976). W wyniku tych procesów na wschód od Łaby i Soławy uformowały się nowe społeczności (w jakimś stopniu dotyczy to również Turyngii) oraz terytoria bezpośrednio lub pośrednio związane politycznie z Rzeszą Niemiecką. Prócz osadników z zachodu, w procesie powstawania tych nowych struktur społecznych i politycznych, brała udział także miejscowa ludność słowiańska i bałtycka (ta ostatnia przede wszystkim w Prusach Wschodnich). Dzisiejsi badacze tę nową jakość społeczno-polityczną funkcjonującą w czasach średniowiecza nazywają Slavia Germanica lub Germania Slavica. Badacze zwracają uwagę, że powstała ona na skutek połączenia żywiołu germańskiego i słowiańskiego, przy zaistnieniu nowych uwarunkowań społeczno-gospodarczych, charakterystycznych dla wdrażanego od podstaw nowego systemu osadniczego i gospodarczego (Mühle 2020).

W ten sposób, obok pierwotnej części społeczeństwa niemieckiego, zachodnioniemieckich dawnych plemion (Altstämme), uformowała się na wschodzie nowa część, wschodnioniemieckie nowe plemiona (Neustämme). Podział ten odpowiadał podziałowi kontynentu europejskiego na Starą i Nową Europę. Stąd postulat, by badania nad historią Niemiec Wschodnich przyporządkować do studiów nad dziejami tej drugiej, czyli Europy Środkowo-Wschodniej (Zernack 2014).

Te dwie części społeczeństwa różniły się od siebie nie tylko miejscem i sposobem powstania, ale od samego początku także systemem społeczno-gospodarczym, osadniczym i prawno-ustrojowym. Niezależnie od tego, pod koniec XIX wieku odrębność społeczno-gospodarczą niemieckiego wschodu dostrzegli ówcześni badacze. Zyskała on określenie Ostelbien (Wschodnie Połabie), 
którym obejmowano wszystkie niemieckie prowincje na wschód od Łaby i Soławy, od Saksonii po Prusy Wschodnie (Weber 1993; Kortus 2004). Na tle Niemiec Zachodnich miał się on wyróżniać odmiennymi cechami gospodarczymi, kulturowymi, politycznymi, językowymi i systemem osadniczym (Reif 1994; Hardt 1999; Wagner 2005; Eddie 2008; Filip 2012; Siatkowski 2015; Hawes 2018). Z uwagi na te okoliczności strefa dawnego Limes Sorabicus utrzymywała charakter granicy społeczno-gospodarczej i kulturowej. Narzuca się w związku z tym przypuszczenie, że ta dziewiętnastowieczna odrębność obszaru na wschód od Łaby (np. gospodarka folwarczna) mogła mieć swoje korzenie w szczególnych cechach tego regionu uformowanych w wyniku procesów osadniczych mających miejsce w średniowieczu, świadcząc na korzyść koncepcji długiego trwania. Należałoby więc przyjrzeć się, które z elementów krajobrazu społeczno-gospodarczego i kulturowego miałyby decydujący charakter dla uformowania i utrzymania wspomnianych odrębności obszaru na przestrzeni dziejów.

\section{Pochodzenie ludności wschodnich Niemiec w świetle badań genetycznych}

Obserwowany jeszcze w XX wieku proces germanizacji ludności słowiańskiej i bałtyckiej (np. Mazurów i Litwinów Pruskich w Prusach Wschodnich) skłania do hipotezy, że ludność rodzima mogła stanowić znaczną część przodków późniejszych społeczności wschodnioniemieckich, co mogło mieć wpływ na formowanie odrębności tego regionu, tak w stosunku do rdzennych terytoriów germańskich, jak i do ziem, które zachowały swój słowiański (bałtycki) charakter. W przypadku Prus Wschodnich badania demografów historycznych wskazują, że większość przodków tamtejszych Niemców była bałtyckiego pochodzenia (Kossert 2004; Jurkat 2005). Dla całego niemieckiego Ostelbien Walter Kruse (1929), w oparciu o wyniki badań antropologii fizycznej, szacował udział słowiańskich przodków na 43\%. Zdaniem Mikołaja Rudnickiego (1936) była to liczba zaniżona, gdyż uwzględniała przede wszystkim ludność miejską. Niezależnie od tego, dla wszystkich tych regionów, prócz zjawiska niemieckiego osadnictwa, poświadczony został również proces germanizacji miejscowej ludności słowiańskiej i jej współudział, wraz z napływającą z zachodu ludnością niemiecką, w kształtowaniu się nowych wschodnioniemieckich społeczności regionalnych (Kaczmarczyk 1953; Strzelczyk 1976; Kirsch 2004; Piskorski 2005, Lübke 2014). Zakładając masowość tego zjawiska, strefa dawnego Limes Sorabicus stanowiłaby w ramach niemieckiego obszaru etnicznego granicę o charakterze reliktowym także w sensie genealogicznym, oddzielając potomków pierwotnych Germanów (Sasów, Turyngów, Franków) od ludności, której przodkowie byli w znacznym stopniu pochodzenia słowiańskiego i bałtyckiego. Obok nowych warunków, jakie stwarzał proces kolonizacji, autochtoniczne pochodzenie części ludności mogło 
również odegrać istotną rolę $w$ kształtowaniu się odrębnych, widocznych niekiedy do dzisiaj cech wschodnich Niemiec, tak w zakresie kultury, jak i sfery społeczno-gospodarczej.

Ostatnio z pomocą $\mathrm{w}$ tych analizach przychodzą najnowsze metody badań genetycznych. Szczególnie zaawansowane dla pogranicza niemiecko-słowiańskiego są analizy polimorfizmu chromosomu Y. Dowodzą one istnienia wyraźnego uskoku genetycznego w strefie dawnego Limes Sorabicus związanego ze zróżnicowaniem udziału linii męskich R1a po obu jej stronach (ryc. 1). W rdzennych społecznościach północnosłowiańskich i bałtyckich nosiciele haplogrupy R1a stanowią bardzo duży odsetek (40-65\%), podczas gdy w rdzennych społecznościach zachodniogermańskich bardzo niski (4-8\%). Względnie wysoki udział nosicieli haplogrupy R1a we współczesnych i dawnych wschodnioniemieckich społecznościach regionalnych wskazuje na znaczący udział potomków Słowian i Bałtów w formowaniu się wschodnioniemieckich grup regionalnych (Kowalski 2020).

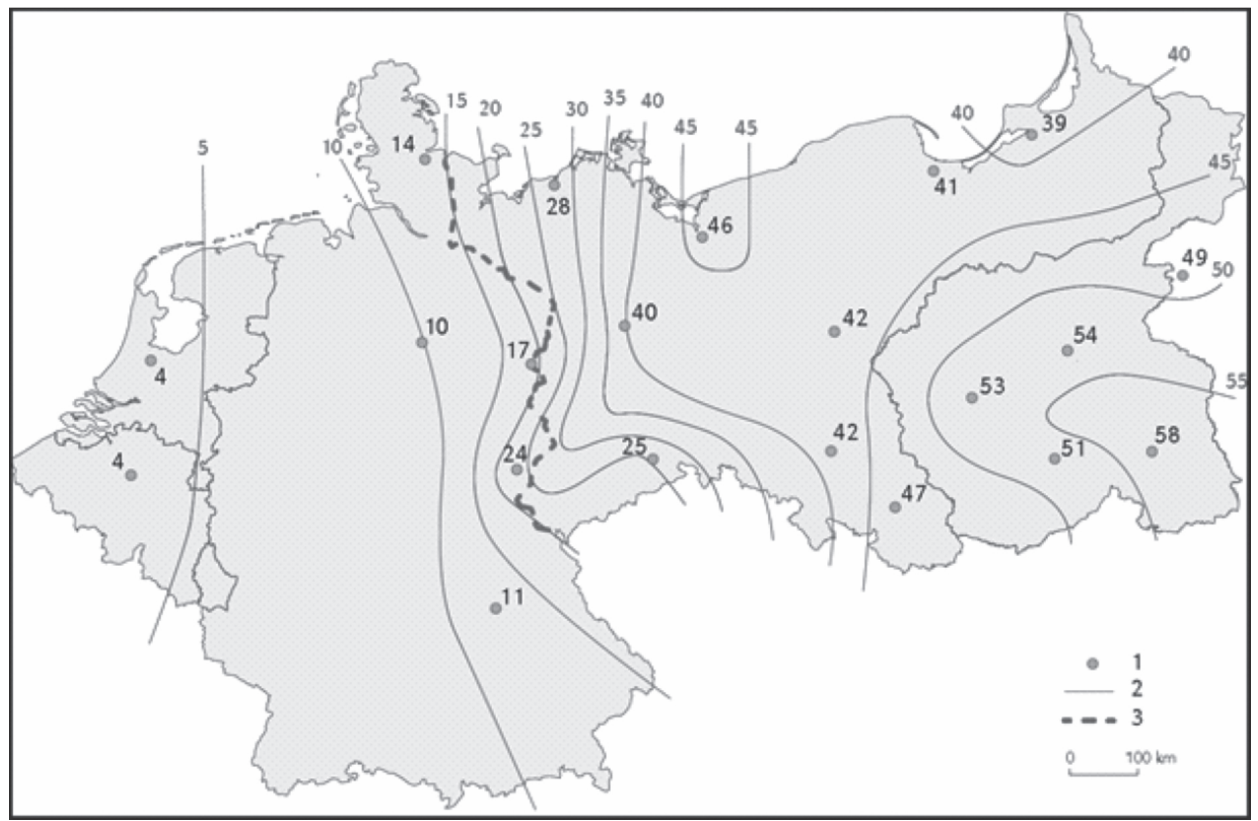

Ryc. 1. Udział nosicieli haplogrupy R1a w populacjach północnej części Europy Środkowej przed 1914 r. 1 - punkty referencyjne z wartościami, 2 - izolinie udziału R1a, 3 - Limes Sorabicus (linia Łaby-Soławy)

Źródło: oprac. własne na podstawie M. Kowalski (2020)

W Meklemburgii i Saksonii linie męskie wywodzące się z ludów słowiańskich zostały nieznacznie zdominowane liczebnie przez linie męskie przybyłe z zachodu. W Brandenburgii, Pomorzu Szczecińskim, Dolnym Śląsku i Prusach 
Wschodnich linie męskie wywodzące się z ludów słowiańskich i bałtyckich przeważały (tab. 2). Z uwagi na dominacje w procesach migracyjnych mężczyzn, można przypuszczać, że udział miejscowych linii żeńskich był/jest jeszcze większy (Kowalski 2020).

Tabela 2. Szacunkowy udział (\%) przodków męskich pochodzenia bałtyckiego i słowiańskiego w populacjach dawnych (przed 1914 r.) i obecnych regionów wschodnioniemieckich na podstawie analizy polimorfizmu chromosomu $\mathrm{Y}$

\begin{tabular}{lcc}
\hline \multicolumn{1}{c}{ Region } & Przed 1914 r. & Obecnie \\
\hline Prusy Wschodnie & 74,0 & nd. \\
\hline Pomorze Szczecińskie & 67,5 & nd. \\
\hline Dolny Śląsk & 62,0 & nd. \\
\hline Brandenburgia & 58,3 & bd. \\
\hline Meklemburgia & 37,8 & $42,9^{\mathrm{a}}$ \\
\hline Saksonia & 33,4 & $40,5^{\mathrm{b}}$ \\
\hline Ostelbien (powyższe łącznie) & 50,5 & $\mathrm{nd}$. \\
\hline Turyngia & 30,8 & $\mathrm{bd}$. \\
\hline Saksonia-Anhalt & 18,3 & $30,9^{\mathrm{c}}$ \\
\hline
\end{tabular}

Objaśnienia: a) - Rostock, b) - średnia dla Drezna (45,1\%) i Lipska $(35,8 \%)$, c) - średnia dla Magdeburga $(25,4 \%)$ i Halle $(36,3 \%)$

Źródło: oprac. własne na podstawie M. Kowalski (2020).

Liczby zaprezentowane w tabeli 2 sugerują wzrost odsetka przodków pochodzenia słowiańskiego w dzisiejszych landach wschodnich pomiędzy 1914 rokiem a czasami najnowszymi. Wydaje się to zrozumiałe biorąc pod uwagę ewakuację, przymusowe przesiedlenia oraz dobrowolne migracje ludności niemieckiej z dawnych wschodnich prowincji w wyniku II wojny światowej. Prawie 1/4 ludności NRD stanowili przesiedleńcy ze wschodu (Kleßmann 2014). Ludność ta posiadała szczególnie dużo przodków pochodzenia słowiańskiego i bałtyckiego, co musiało podnieść ich udział w populacjach regionalnych na zachód od Odry i Nysy Łużyckiej.

Opisywane zjawisko ma masowy charakter, ale można je także prześledzić na przykładzie konkretnych rodzin niemieckich lub pochodzenia niemieckiego. Badania wykazały, że do genetyczno-genealogicznych linii męskich występujących przede wszystkim u Słowian lub Bałtów należy niemiecki ród von Amsberg, którego jeden z przedstawicieli, Wilhelm-Aleksander, od 2013 roku zasiada na tronie Niderlandów. To samo dotyczy innego niemieckiego rodu szlacheckiego, von Sydow, którego przedstawicielem był znany szwedzki aktor Max von Sydow. Badania genetyczne dowodzą, że przedstawiciele obu rodów są nosicielami 
haplogrupy Y-DNA R1a-Z280, określanej mianem „bałto-słowiańskiej”, a najwcześniej znani przodkowie zamieszkiwali Pomorze Szczecińskie. Nosicieli haplogrupy Y-DNA R1a-Z92 (tzw. „bałtyjskiej”) stwierdzono natomiast z wywodzącej się z Prus Wschodnich (Krzyżbork) rodzinie Tolkien, do której należał znany pisarz brytyjski John Tolkien. Badania którym poddali się członkowie rodu Luter mogą natomiast wskazywać, że Marcin Luter, pochodzący z Turyngii przywódca Reformacji, mógł być nosicielem haplogrupy Y-DNA I2a1b-L621, określanej mianem „dynarsko-słowiańskiej”. Haplogrupę Y-DNA R1a-M458 (tzw. zachodniosłowiańską) stwierdzono natomiast w materiale genetycznym Rudolfa Hessa, nazistowskiego polityka, którego męscy przodkowie wywodzili się z Czech (Hay 2021). W tym wypadku możemy mówić o długim trwaniu miejscowych linii genealogicznych, choć jak widać w czasach bliższych współczesności część ich przedstawicieli porwały różnego rodzaju procesy migracyjne.

\section{Proces germanizacji}

Źródła historyczne potwierdzają, że nowe społeczności niemieckie na wschód od Limes Sorabicus w okresie kolonizacji wschodniej (XII-XIV w.) powstawały przy udziale miejscowych Słowian i Bałtów, którzy ulegali szybkiej akulturacji pod wpływem emigrantów z zachodu (Kirsch 2004; Lübke 2014). Były jednak znaczne obszary, gdzie emigranci prawie w ogóle się nie osiedlali, a germanizacja ludności słowiańskiej i bałtyckiej trwała znacznie dłużej. Tak było np. na wyspie Rugia (zachodnia część Pomorza Zachodniego), gdzie język słowiański przetrwał co najmniej do początku XV wieku (Lübke 2014). W XIX wieku Wincenty Pol zauważa, że resztki pierwotnego zaludnienia Rugii pozostały na półwyspie Mönchgut, a tamtejsza ludność zwana Rybakami (Reboken) wyróżnia się strojem, obyczajami, a przede wszystkim mową, w której funkcjonują słowa słowiańskiego pochodzenia (np. reba, żywot, ziemia, dziewka, perekop, piorun itd.) (Pol 1989).

Znacznie dłużej trwała germanizacja ludności słowiańskiej we wschodniej części Pomorza Zachodniego. Przekazy i spostrzeżenia sugerują, że osadnictwo słowiańskie bardzo długo sięgało na zachodzie aż po Dziwnów. Do XVIII wieku miejscowa ludność uległa jednak germanizacji, choć o jej pochodzeniu świadczyły zwyczaje oraz charakterystyczna wymowa języka niemieckiego (Filip 2012). W latach 30. XX wieku na Pomorzu Zachodnim, pomimo znaczącego wzrostu liczby ludności ogółem, było już tylko ok. 5 tys. Kaszubów zamieszkujących okolice Bytowa i Lęborka (Skóra 2004).

Do XVI, a nawet początków XVII wieku, język słowiański używany był również na pograniczu Meklemburgii i Brandenburgii, najdłużej w okolicach Grabowa, Ludwigslust i Dömitz (Tetzner 1902; North 2015). Przedłużeniem tego słowiańskiego obszaru osadniczego był sąsiedni Wendland, położony już za Łabą, we wschodniej części dzisiejszego kraju związkowego Dolna Saksonia 
(okolice Lüneburga). Język słowiański przetrwał tu do połowy XVIII wieku, a odrębność etnograficzna miejscowej ludności utrzymywała się jeszcze na przełomie XIX i XX wieku. Karol Arnošt Muka, który prowadził tam wówczas badania zauważył, że pomimo germanizacji ,zachowała się w tamtejszej krainie stara słowiańska grupa narodowa z typem i sposobem osiedlenia, zwyczajami i obyczajami, w charakterze i poglądach obywateli niezmieniona do dziś" (Muka 1904).

Do dzisiaj swoją odrębną tożsamość i język zachowała niewielka grupa (20-60 tys. osób) ludności słowiańskiej w centralnej części Łużyc, podzielonych pomiędzy Brandenburgię i Saksonię (Szczepankiewicz-Battek 2005; Dołowy-Rybińska 2011). W czasach nowożytnych obszar osadnictwa tej grupy był jednak znacznie większy, rozciągając się między Dreznem i Zgorzelcem a Frankfurtem i Berlinem, obejmując również wschodnią część dawnej prowincji pruskiej Saksonia (Šołta 1984).

Podobnie wyglądał proces germanizacji polskojęzycznych mieszkańców Dolnego Śląska. W wyniku średniowiecznej kolonizacji osadnictwo niemieckie skoncentrowało się przede wszystkim w Sudetach i na ich przedpolu (Cetwiński 2001), choć i tu mieszało się z polskim (Schich, Stephan 2015). Na obszarach położonych bardziej na północ, przede wszystkim w prawobrzeżnej części Dolnego Śląska, skupiska ludności polskojęzycznej utrzymały się znacznie dłużej. Jeszcze w końcu XVIII wieku język polski dominował w okolicach Oławy, Sycowa, Namysłowa, choć do początków XX wieku prawie całkowicie wyszedł z użycia (Kaczmarczyk 1953; Kokot 1973; Janczak i in. 1976).

Znaczenie procesów germanizacji miejscowej ludności w kształtowaniu się wschodnioniemieckich społeczności regionalnych potwierdzają również wspomniane na wstępie studia nad demografią historyczną Prus Wschodnich. W regionie tym, prócz Niemców mieszkali Prusowie, Polacy (Mazurzy, Warmiacy) i Litwini. Język staropruski utrzymał się w Natangii do końca XVI wieku, a w Sambii nawet do początków XVIII wieku (Zabrocki 1961). Języki polski i litewski przetrwał do XX wieku (Srokowski 1937). Badania wykazują, że w 1708 roku pochodzenia (staro)pruskiego było 33,8\% mieszkańców Prus Wschodnich, litewskiego 21,2\%, co razem stanowiło 55\% mieszkańców regionu. To samo badanie ustaliło odsetek mieszkańców pochodzenia niemieckiego na $24,6 \%$, a polskiego (mazurskiego) na 18,8\% (Kossert 2004; Jurkat 2005). Wobec prawie całkowitej germanizacji językowej lub tożsamościowej mieszkańców Prus Wschodnich w I połowie XX wieku i ostatecznej migracji tej społeczności do Niemiec po II wojnie światowej, liczby te w dużym przybliżeniu muszą dotyczyć także dwudziestowiecznych wschodniopruskich Niemców (Kowalski 2020). Skala opisywanych zjawisk bardzo dobrze wpisuje się w liczby uzyskane dla Prus Wschodnich na podstawie badań genetycznych (tab. 2), potwierdzając - pomimo akulturacji - masowy charakter długiego trwania potomków ludności zamieszkującej te obszary przed kolonizacją niemiecką. 
Proces germanizacji widoczny jest na przykładzie poszczególnych rodów. Należeli do nich również książęta słowiańscy, którzy przyjęli zwierzchnictwo niemieckie lub związali się z niemieckim systemem społeczno-politycznym i kulturowym za pośrednictwem czeskim. Dotyczyło to m.in. Piastów śląskich. Ostatnim z nich był Jerzy Wilhelm (Georg Wilhelm), który do swojej śmierci w 1675 roku władał księstwem legnicko-wołowsko-brzeskim (Czechowicz 2007). Nieco wcześniej wymarł ród Gryfitów, władców Pomorza Szczecińskiego. Jego ostatnim przedstawicielem, do swojej śmierci w 1637 roku sprawującym rządy w dziedzicznym księstwie, był Bogusław (Bogislaw) XIV (Rymar 2005). Za potomków książąt pomorskich uważani byli także książęta Potbus z Rugii, zajmujący w XIX wieku wysoką pozycję w systemie społeczno-politycznym Królestwa Prus. Ich ostatni przedstawiciel w linii męskiej, Wilhelm Malte I, zmarł w 1854 roku (Schoebel 2003). Do dzisiaj natomiast istnieje ród władców Meklemburgii, wywodzący się od obodrzyckiego księcia Niklota. Do 1918 roku władał on księstwem Meklemburgii wchodzącym w skład II Rzeszy Niemieckiej (Lippert 2001). Słowiańskie korzenie miały również inne znane rody wschodnioniemieckie. Dla przykładu można tu wskazać takie osoby, jak Ludwik Yorck von Wartenburg (1759-1830), Helmut von Moltke (1800-1891), Walter von Brauchitsch (1881-1948), Erich von Manstein (1887-1973), czy ostatnio Angela Merkel, z domu Kasner (ur. 1954), której ojciec, ewangelicki teolog i duchowny, urodził się jeszcze jako Horst Kaźmierczak (1926-2011) (von Manstein 1958; Klec-Pilewski 1991; Schmilewski 2001; Thies 2012; Kornelius 2014). Nazwiska i cechy genetyczne dzisiejszych mieszkańców landów wschodnich wskazują, że przypadki tych osób nie były wyjątkami, potwierdzając fakt długiego trwania linii genealogicznych na tym obszarze.

Fakty te nie znajdowały jednak i wciąż nie znajdują odzwierciedlenia w powszechnej świadomości miejscowych Niemców. Przykładem może być tu wspomnieniowa książka znanego niemieckiego wojskowego Gerd-Helmuta Komossy (ur. 1924 r.). Jest to cenny obiekt analizy, gdyż przedstawia poglądy laika w kwestiach dziejów etnicznych, oparte na popularnym przekazie tradycji narodowej niemieckiego wschodu. W książce tej nigdzie nie możemy odnaleźć odniesienia do słowiańskich (mazurskich) korzeni autora, choć świadczy o tym jego nazwisko i miejsce pochodzenia (Mazury). Według niego, obszar Mazur był przed przybyciem Krzyżaków bardzo słabo zasiedlony i porośnięty puszczą. Dopiero Zakon miał te tereny przystosować do potrzeb rolniczych i zasiedlić przybyszami z Niemiec. Autor wspomina również o późniejszych imigrantach: protestantach z okolic Salzburga i francuskich Hugenotach. Wszyscy oni mieli zmieszać się z nieliczną ludnością bałtycką, a także z Mazowszanami (Komossa 2006). Tych ostatnich wymienia autor na końcu, jakby zapominając (nie wiedząc?), że to oni stanowili główny trzon ludności zasiedlającej Mazury i to im region ten zawdzięcza swoją nazwę, a proces ich ostatecznej germanizacji przebiegał za jego 
życia. W tym kontekście nie może dziwić, że słowiańskie (bałtyckie) pochodzenie nie jest również elementem tożsamości Niemców z regionów, które uległy germanizacji znacznie wcześniej.

\section{Ślady językowe}

Znaczenie Limes Sorabicus jako granicy oddzielającej w przeszłości świat germański od słowiańskiego uwidacznia się bardzo wyraźnie za sprawą dzisiejszej toponimii. Widać to m.in. w przypadku nazw miejscowości. Na zachodzie od tej granicznej linii (strefy) nazwy pochodzenia słowiańskiego nie występują, na wschód od niej stanowią znaczną, na niektórych obszarach przeważającą liczebnie część. Dotyczy to zarówno dużych miast (Chemnitz, Dessau, Dresden, Leipzig, Rostock, Schwerin itd.), jak i małych wiosek (np. Belitz, Dobin, Jellen, Krakow, Rosin, Tarnow czy Teldau w Meklemburgii). Nazwy tych miejscowości charakteryzują się bardzo często charakterystycznymi końcówkami: „-tz”, „-ow”, „-au”, czy „-in” (Kleiner Atlas der Siedlungsnamen...), odpowiadając polskim końcówkom „-ce”, ,-ów”, „-wa”, czy „-in”.

Podobne zjawisko ujawnia się w sferze antroponimii, gdyż we wschodniej części Niemiec znaczna część mieszkańców nosi nazwiska o słowiańskim rodowodzie (Berger 1999; Immel 2006; Kowalski, Śleszyński 2010). Bardzo często są to nazwiska osób pochodzących z polsko-niemieckiego lub polsko-czeskiego pogranicza, noszących po prostu polskie lub czeskie nazwiska (Kowalski, Kaminski, Nowak itd.), będące świadectwem stosunkowo niedawnych migracji. Częściej jednak mamy do czynienia z nazwiskami uznawanymi za niemieckie, ale powstałymi przez asymilację słów słowiańskich lub uformowanych pod wpływem oddziaływania zjawisk językowych charakterystycznych dla języków słowiańskich. Do tych nazwisk zalicza się m.in. nazwiska kończące się na „-ke” (Buschke, Klaffke, Meschke, Radtke, Zielke itd.) powstałe np. z nazw polskich przez wymianę polskiego wygłosowego „-a” na niemieckie „-e” lub odwrócenie słowiańskiego przyrostka „-ek” na dolnoniemieckie „-ke” (Breza 1987). Wśród typowo niemieckich nazwisk należących pod względem liczebności do pierwszego tysiąca najpopularniejszych, a jednocześnie wykazujących zwiększony udział na wschód od linii Łaby-Soławy i mogących wykazywać wpływy słowiańskie lub swoiste cechy wschodnioniemieckie, wymienić można następujące: Bartsch, Behnke, Dietze, Fritsche, Fritzsche, Gehrke, Hanisch, Hentschel, Jahnke, Janke, Lemke, Liedtke, Linke, Lüdtke, Mielke, Nitsche, Nitschke, Noack, Opitz, Pietsch, Pusch, Radtke, Reinke, Starke, Thieme, Tietz, Uhlig, Wilke (Stöpel 2005) (ryc. 2).

Występowanie tego typu nazwisk na północnym wschodzie Niemiec było swego rodzaju cechą wyróżniającą. Jedno z nich, Piefke, wywodzone przez językoznawców ze słowiańskiego słowa „piwo” i nawiązujące do takich polskich 

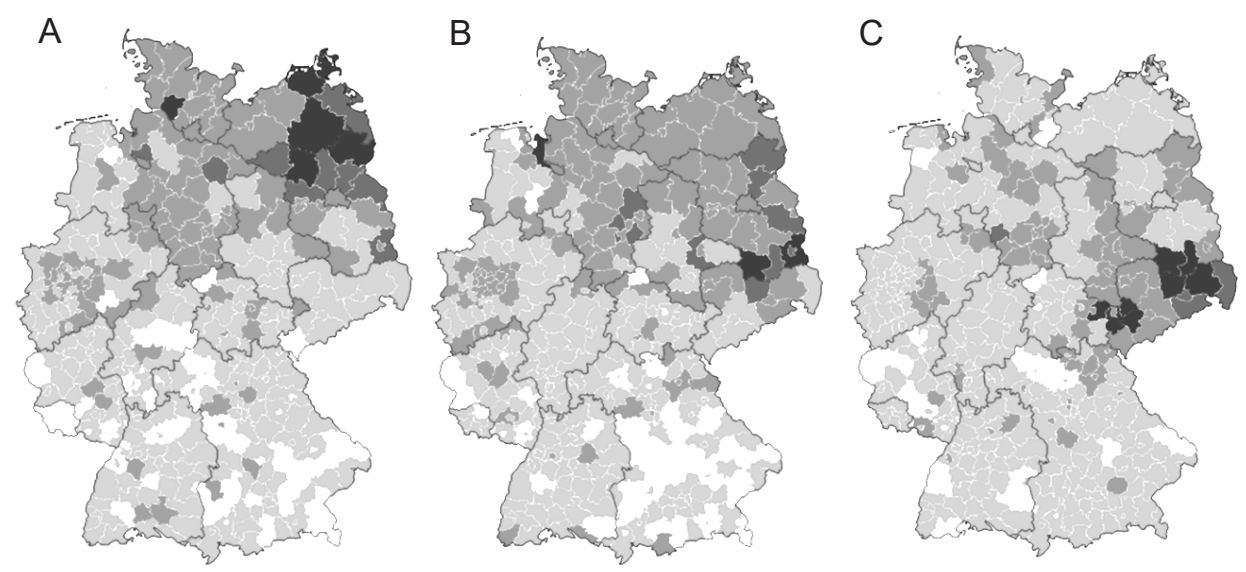

Ryc. 2. Rozmieszczenie osób noszących wybrane nazwiska typowe dla Niemiec wschodnich: Mielke (A), Janke (B) i Opitz (C) według udziału w powiatach Źródło: Ch. Stöpel (2005)

nazwisk, jak Piwek, Piwko, Piwka, stało się nawet popularnym etnopaulizmem, którego Austriacy używali wcześniej na określenie Prusaków, a obecnie na określenie wszystkich Niemców z północy (Mally 1974).

Na wschód od Łaby i Soławy ukształtowały się również nowe dialekty języka niemieckiego: wschodniośrodkowoniemieckie (turyngijsko-górnosaski, śląski, górnopruski) oraz wschodniodolnoniemieckie (meklemburski, marchijski, pomorski, dolnopruski). Dochodzi jeszcze dialekt wschodniobawarski w Austrii, również powstał na obszarach zamieszkanych wcześniej przez Słowian. W zasobie słownikowym tych dialektów zanotowano ponad 4 tys. pożyczek z języków słowiańskich, co świadczy o bardzo silnym wpływie Słowiańszczyzny na ich rozwój. Niektóre z tych pożyczek trafiły nawet do niemieckiego języka literackiego: Grenze - granica, Kobel - kobyła, Quark - twaróg, Jauche - gnojówka, pomale - powoli, dalli - dalej, naprzód i wiele innych (Siatkowski 2015).

\section{Uwarunkowania społeczno-gospodarcze}

Powstający w średniowieczu w wyniku ekspansji politycznej Niemiec i napływu osadników z zachodu nowy ład na obszarze Slavia Germanica wiązał się z całkowitą zmianą struktur, wykształceniem nowych form osadnictwa, gospodarki, form prawnych i społecznych. Prawie całkowicie wyparty został dawny słowiański sposób bycia, ale także życie przybyszów z zachodu uległo gruntownej zmianie. Ci ostatni nie przynieśli ze sobą gotowego wzorca osadnictwa i gospodarki, lecz wykształcili go na miejscu przy aktywnym współudziale autochtonicznej ludności. Zmiany w krajobrazie były więc wynikiem szczególnej symbiozy 
niemiecko-słowiańskiej. Osady odnawiane w starych lokalizacjach lub zakładane na nowych terenach miały formę planowych owalnic, ulicówek, wsi placowych lub łańcuchówek, układów nie spotykanych w Niemczech zachodnich. Nowe zasady gospodarowania z założenia były nastawione na nowoczesną trójpolówkę oraz gwarantowały sprawiedliwy, związany z wielkością przydzielonych gospodarstw, pobór podatków i danin. Oparte na zuniformizowanych przepisach struktury prawne gwarantowały samorządność i sądownictwo patrymonialne. W niektórych miejscach przetrwały jednak starsze sposoby prowadzenia gospodarki i osadnictwa, choć i tam wprowadzano pewne zmiany (Mühle 2020).

Przyjmując koncepcję długiego trwania należy przyjąć, że różnice te miały wpływ na późniejszą ewolucję stosunków społeczno-gospodarczych i politycznych. Nie ma bowiem wątpliwości, że w czasach nowożytnych ugruntował się podział na Niemcy zachodnie, gdzie dominowała gospodarka czynszowa oraz na Niemcy wschodnie, gdzie dominowała gospodarka folwarczno-pańszczyźniana. To zróżnicowanie związane jest ze zjawiskiem dualizmu gospodarczego Europy. Podczas gdy w Europie Zachodniej następował stopniowy rozwój stosunków kapitalistycznych, na Wschodzie obserwowano proces wtórnego poddaństwa feudalnego, które oprócz wschodu Niemiec objęło również Polskę, Czechy i Węgry. Według W. Wittlicha ustrój folwarczno-pańszczyźniany zapanował w tzw. starych Prusach (Pomorze, Brandenburgia, Prusy Wschodnie, Śląsk), Meklemburgii, Szlezwiku-Holsztynie i Górnych Łużycach. W Lauenburgu i Saksonii pruskiej (dzisiaj Saksonia-Anhalt) panować miał ustrój mieszany zbliżony do folwarczno-pańszczyźnianego. Niezupełnie jasny był natomiast ustrój w Królestwie Saksonii właściwej, choć zbliżał się silnie do ustroju czynszowego. W pozostałej części Niemiec miał dominować ustrój czynszowy w czystej postaci (Wittich 1892; Orzechowski 1957).

Przyjmując znaczenie procesów długiego trwania należałoby przyjąć, że rozwój wtórnego feudalizmu na obszarze na wschód od Łaby i Soławy był konsekwencją modernizacji jaką przyniosła ze sobą kolonizacja na prawie niemieckim. Sławomir Gawlas (2000) zauważa, że względna archaiczność struktur społecznych krajów położonych na uboczu procesów rozwojowych - a do takich niewątpliwie należały ziemie leżące na wschód od linii Łaby-Soławy - ułatwiła panującym posłużenie się w swoim interesie zestawem koncepcji prawno-ustrojowych i socjotechnicznych recept racjonalnej organizacji podstaw ich władzy. W mechanizmach tych należy szukać przyczyn powstawania zjawiska autokratyzmu peryferyjnego. Modernizacja pod presją władzy, zmieniając przebieg i mechanizm procesów autogennych, prowadziła najczęściej do długotrwałych zaburzeń wewnętrznego rozwoju. Należy sądzić, że niepowtarzalność ewolucji kształtu ustrojów krajów środkowoeuropejskich ma swoje sięgające głęboko w przeszłość przyczyny. W tym należy najprawdopodobniej widzieć powody jednostronności rozwoju struktury społecznej krajów Europy Środkowej, zwracając uwagę na takie cechy, jak postępujące rozwarstwienie w warunkach dominacji form za- 
leżności osobistej i procesom oddolnej dezintegracji struktur państwowych pod wpływem rozwoju władztwa gruntowego i terytorialnego (Gawlas 2000).

Spostrzeżenia te wpisują się w poglądy takich badaczy, jak Jenő Szücs (1995) czy Francis Fukuyama (2012), dostrzegających kilka modeli rozwojowych w Europie. Ich zdaniem uwarunkowania charakterystyczne dla Europy Zachodniej (na zachód od Łaby) dały możliwość rozwoju absolutyzmu opartego na równowadze pomiędzy szlachtą a mieszczaństwem. Zachowany został znaczący liberalizm (brak poddaństwa, znaczna autonomia szlachty względem monarchy), co następnie umożliwiło przejście do modelu burżuazyjnego. W Europie Wschodniej dominacja szlachty uniemożliwiała władcy wzmocnienie swej pozycji przy wykorzystaniu mieszczaństwa, co prowadziło do wzrostu znaczenia możnowładców i służącemu ich interesom osłabieniu centrum władzy. Tego osłabienia uniknęły m.in. Prusy, którym pomimo słabości mieszczaństwa i poddaństwa chłopów, udało się ograniczyć autonomię stanu szlacheckiego. Należy więc dostrzec dwa podtypy wschodnioeuropejskiej ścieżki rozwojowej. Jeden charakterystyczny m.in. dla Prus (Niemiec Wschodnich), drugi dla Polski. W obu, w odróżnieniu do zachodu, dostrzega się słabość mieszczaństwa i umocnienie poddaństwa. W pierwszym, pruskim, służy ono jednak przede wszystkim ośrodkowi centralnemu, a dopiero w drugiej kolejności, podporządkowanej i współpracującej z tym centrum, szlachcie (junkrom). W drugim, polskim, służy on przede wszystkim szlachcie i magnatom, co wiąże się z osłabieniem władzy centralnej.

Hagen Schulze (2012) zauważa, że najpotężniejsze ze wschodnioniemieckich państw, czyli brandenbursko-pruska monarchia, upodobniło się do powiększonego obszaru dworskiego (patrymonialnego junkierskiego majątku z folwarkiem) z charakterystycznym dla Europy na wschód od Łaby osobistym poddaństwem chłopów i niepełną, lenną, własnością szlachecką. Patrymonialny autokratyzm lub uprzywilejowana pozycja szlachty odróżniały Niemcy wschodnie od zachodnioniemieckich księstw terytorialnych, gdzie autokratyczne tendencje były hamowane silną pozycją liberalnego mieszczaństwa (Wawrykowa 1976).

Silna pozycja junkrów na wschodzie Niemiec, lojalnie współpracujących z miejscowymi władcami powodowała, że także dziewiętnastowieczna likwidacja systemu feudalnego w sferze gospodarczej przeprowadzona została przy zachowaniu ich interesów. Przekształcenie to zostało nazwane pruską drogą do kapitalizmu w rolnictwie. Dotychczasowi panowie feudalni przekształcili się w kapitalistycznych producentów zachowując znaczącą pozycję w życiu społeczno-gospodarczym i politycznym. Tylko część chłopów utrzymała swoje dotychczasowe gospodarstwa zwolnione ze świadczeń na rzecz szlachty. Najbiedniejsi przeszli natomiast do warstwy robotników rolnych zatrudnianych w ziemiańskich folwarkach. Rozwiązania te, podtrzymując znaczenie szlachty i wielkoobszarowego rolnictwa, utrzymały odmienność życia społeczno-gospodarczego i politycznego Ostelbien w stosunku do zachodnich regionów Niemiec (Orzechowski 1957). 
W późniejszym systemie socjalistycznym Niemiec wschodnich także można dostrzec swego rodzaju kontynuację wcześniejszych stosunków, zarówno feudalnych, jak i związanego z pruską drogą do kapitalizmu w rolnictwie. Antoni Mączak (1998) zauważa, że w warunkach gospodarki nakazowo-rozdzielczej w Polsce, państwo spełniało rolę wielkiego latyfundysty. Rolnicy oddawali gros swych plonów jako podatek lub w postaci „obowiązkowych dostaw”. Resztę musieli sprzedawać państwu po cenach monopolistycznych. Państwowy monopol handlu produktami rolnymi, wprowadzony w państwach obozu socjalistycznego, przypominał na dużą skalę organizację handlu i produkcji w dawnych magnackich latyfundiach. W przypadku Niemieckiej Republiki Demokratycznej - inaczej niż w Polsce - doszła do tego prawie całkowita kolektywizacja rolnictwa. Początkowo, w latach 40. XX wieku, nastąpiła parcelacja wielkich majątków ziemskich pomiędzy indywidualnych rolników. W latach 50. rozpoczęła się jednak akcja likwidacji wszystkich indywidualnych gospodarstw i tworzenie w ich miejsce rolniczych spółdzielni produkcyjnych (Landwirtschaftliche Produktionsgenossenschaft-LPG). Objęła ona ponad 90\% ogólnego areału ziemi rolniczej (Jurek 1975; Laschewski 1998). Dotychczasowi właściciele, pomimo utrzymania kolektywnego prawa własności, stali się de facto pracownikami najemnymi tych wielkich gospodarstw ziemskich, co upodabniało ich do pracowników dawnych folwarków junkierskich. Pruska droga do kapitalizmu w rolnictwie utrzymała tradycje autokratyczne w całym państwie i zależność części mieszkańców wsi od junkrów. System socjalistyczny w Niemczech wschodnich podtrzymał autokratyczne tradycje w polityce, a w życiu społeczno-gospodarczym nie tylko kontynuował, ale i umocnił zasady pracy kolektywnej. Parafrazując opinię H. Schulze można by powiedzieć, że NRD kontynuowała w dużym stopniu dawne tradycje, gdyż wschodnie Niemcy przekształciły się z powiększonego obszaru dworskiego w powiększoną socjalistyczną spółdzielnię produkcyjną (także poza obszarami wiejskimi).

\section{Sympatie polityczne}

Utrzymanie znaczącej pozycji rolnictwa wielkoobszarowego w gospodarce oraz szlachty w życiu społeczno-politycznym miało olbrzymi wpływ na ideowy charakter społeczeństwa regionów Ostelbien. Badacze podkreślają konserwatywny charakter dominujących $\mathrm{w}$ regionie poglądów politycznych w przeciwieństwie do mieszczańskiego i liberalnego zachodu Niemiec. Znajduje to potwierdzenie w pozycji jaką zajmowała szlachta w systemie władzy. W latach 1890-1918 wśród wszystkich pruskich landratów (naczelników powiatu) 59\% należało do stanu szlacheckiego. O ile jednak w Nadrenii reprezentanci stanu szlacheckiego stanowili tylko $40 \%$ tej kategorii urzędników, to w prowincji pomorskiej aż 86\% (Kucharczyk 2020). 
Ta specyfika Ostelbien, tak jak dzisiejsza wyjątkowość landów wschodnioniemieckich, znajdowała swoje odniesienie w zachowaniach wyborczych ludności. Na wschód od linii Łaby-Soławy zauważyć można w wyborach z lat 1871-1912 ponadprzeciętne poparcie dla protestanckich partii konserwatywnych: Niemieckiej Partii Konserwatywnej (Deutschkonservative Partei-DKP) oraz Niemieckiej Partii Rzeszy (Deutsche Reichspartei - DRP) (ryc. 3). Wyjątek stanowiły jedynie obszary zamieszkane w większości przez katolików i Polaków. Pod koniec tego okresu można dla odmiany zauważyć w południowo-zachodnich, bardziej zurbanizowanych i uprzemysłowionych regionach tego obszaru (gł. Saksonia, Saksonia pruska, Turyngia i Brandenburgia, a więc południowa i centralna część późniejszej NRD) także szczególnie wysokie poparcie - niemające precedensu w innych regionach Niemiec - dla socjaldemokratów, najradykalniejszej partii lewicowej ówczesnego parlamentu Niemiec (ryc. 3). W wyborach do Reichstagu uzyskali oni w Królestwie Saksonii 55\%, w Turyngii 49,7\%, a w Brandenburgii 49,1\% głosów, podczas gdy w Hesji-Darmstadt 39,3\%, Hanowerze 31,8\%, Westfalii 28,8\%, a w Nadrenii tylko $24,2 \%$.
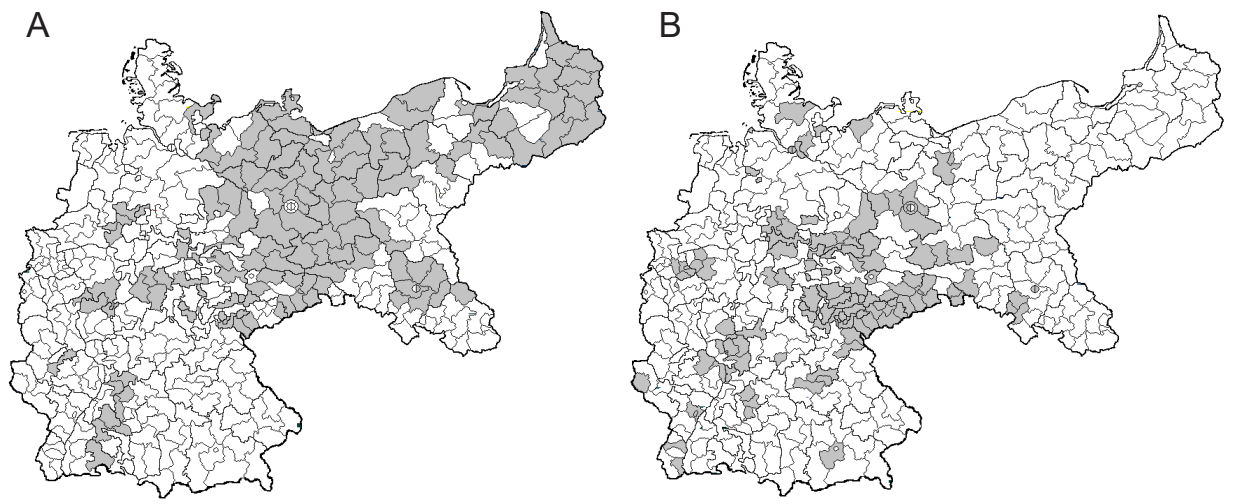

Ryc. 3. Wyniki wyborów do Reichstagu. (A) - okręgi, w których w 1887 r. zwyciężyli konserwatyści (DKP lub DRP), (B) - okręgi, w których w 1912 r. zwyciężyli socjaldemokraci (SPD)

Źródło: oprac. własne na podstawie V. Schröder (2020)

W okresie międzywojennym utrzymało się na wschód od Łaby i Soławy ponadprzeciętne poparcie dla protestanckich konserwatystów zjednoczonych w nowej partii - Niemieckiej Narodowej Partii Ludowej (Deutschnationale Volkspartei - DNVP). W latach 30. ugrupowanie to straciło wielu wyborców na rzecz NSDAP, które właśnie we wschodnich regionach kraju uzyskiwało najwyższe poparcie (najwięcej w Prusach Wschodnich, na Pomorzu, Dolnym Śląsku i wschodniej Brandenburgii). Interesujące, że w niektórych regionach Ostelbien (Brandenburgia, Saksonia, Saksonia pruska, Turyngia) w okresie międzywojennym, podobnie 
jak przed I wojną światową, ponadprzeciętne poparcie zdobywały również radykalne ugrupowania lewicowe, tym razem komuniści i Niezależna Socjaldemokratyczna Partia Niemiec. Podobnie silne poparcie radykalna lewica zdobywała jedynie w Zagłębiu Ruhry oraz innych znaczących ośrodkach miejsko-przemysłowych (Frankfurt nad Menem, Hamburg, Norymberga, Monachium, Hanower, Stuttgart) (patrz: Schröder 2020). Można się domyślać, że tradycje wschodnioniemieckie, związane ze słabością mieszczaństwa, znaczeniem szlachty i rolnictwa, sprzyjały poglądom konserwatywnym, natomiast proletaryzacja społeczeństwa, związana z dużym udziałem robotników rolnych, a następnie także uprzemysłowieniem, sprzyjała w późniejszym okresie ugrupowaniom lewicowym. O ile więc mieszczańskie społeczeństwo zachodu Niemiec prezentowało bardziej umiarkowane sympatie polityczne (liberałowie), o tyle na wschodzie znacznie silniej dochodziły do głosu sympatie dla skrajnych ugrupowań po lewej, jak i po prawej stronie sceny politycznej. Przypomina to trochę sytuację obserwowaną w Niemczech w ostatnich latach.

\section{Podsumowanie}

Niemcy Wschodnie od swoich początków odróżniały się od zachodnich regionów Niemiec. Dotyczyło to m.in. kwestii etnicznych. Wiązało się to z obecnością ludności słowiańskiej i bałtyckiej na wschodzie Niemiec. Początkowo ludność ta stanowiła większość i zamieszkiwała cały obszar Niemiec Wschodnich (Slavia Germanica). Później, w wyniku procesów germanizacji, jej resztki przetrwały jedynie na obrzeżach (Górny Śląsk, Prusy Wschodnie) i w izolowanych miejscach tego obszaru (Łużyce). Niemniej relikty jej obecności wciąż można dostrzec w różnych miejscach i sferach. Dotyczy to m.in. warstwy językowej w postaci toponimii i antroponimii, czy też słowiańskich zapożyczeń leksykalnych w dialektach niemieckich na wschód od Łaby i Soławy. Znaczący udział ludności słowiańskiej i bałtyckiej w formowaniu się miejscowych populacji - co najmniej 50\% w całym dawnym etnicznie niemieckim Ostelbien, co najmniej $2 / 3$ na terenach utraconych na rzecz Polski po II wojnie światowej i co najmniej 40\% w dzisiejszej Saksonii i Meklemburgii - podkreślają natomiast wyniki badań genetycznych.

Słowiańskie pochodzenie znaczącej części przodków nie czyni jednak Niemców ze wschodu Słowianami. O tym decyduje ich język oraz samoświadomość. Należy wziąć pod uwagę poglądy samych zainteresowanych, jak cytowanego powyżej Gerd-Helmuta Komossy. Nie da się oczywiście zaprzeczyć, że ludność Wschodnich Niemiec wykazuje większe podobieństwo do słowiańskich sąsiadów (Polaków, Czechów, Serbów Łużyckich) niż Niemcy z zachodu, ale podobieństwo to nie jest platformą do budowania wspólnoty na bazie tak czy inaczej rozumianej słowiańskości. Cechy te są jedynie podstawą odrębności, uświadamianej lub nie, względem innych niemieckich grup regionalnych. 
Powstanie nowych niemieckich społeczności regionalnych na wschód od Limes Sorabicus wiązało się natomiast z przekształceniami gospodarczymi, osadniczymi i prawno-ustrojowymi, wynikającymi z połączenia tradycji społeczności germańskich i słowiańskich (bałtyckich) pod auspicjami średniowiecznej modernizacji. Wywarły one olbrzymi wpływ na uwarunkowania społeczno-gospodarcze i polityczne Niemiec Wschodnich, odróżniając je - pomimo wielu podobieństw - zarówno od innych krajów Europy Środkowej (Polska, Czechy, Węgry), jak i od Niemiec Zachodnich. Uwarunkowania te odcisnęły się także na późniejszym rozwoju społeczno-gospodarczym i politycznym tego obszaru, który tak jak inne części Europy Środkowej uległ procesom wtórnej feudalizacji. Wiązało się to z umocnieniem znaczenia szlachty, rozwojem gospodarki folwarczno-pańszczyźnianej, niedorozwojem miast i mieszczaństwa oraz upośledzeniem sytuacji ludności chłopskiej.

W tych okolicznościach także przesilenie feudalizmu i wprowadzanie systemu kapitalistycznego miały na tym obszarze swoje szczególne cechy i konsekwencje. Pruska droga do kapitalizmu w rolnictwie wdrażana na większości omawianego obszaru zachowała znaczenie szlachty. Tu jednak rozeszły się drogi wschodnich Niemiec i Polski, gdyż pruskie rozwiązania ominęly zabór rosyjski i austriacki. Nie miały one miejsca także na zachodzie Niemiec, gdzie nie było warstwy junkierskiej i pańszczyźnianych chłopów. Konsekwencją pruskich reform było powstanie licznej warstwy wiejskiego proletariatu, zatrudnionego w ziemiańskich folwarkach. Słabość tradycji obywatelskich, związana z poddaństwem chłopów i podporządkowaniem szlachty władcy, sprzyjała natomiast utrzymaniu tendencji autokratycznych. Te ostatnie były w sąsiedniej Polsce hamowane tradycjami szlacheckiego republikanizmu i zrywów wolnościowych w XVIII, XIX i XX wieku, zaś w Niemczech zachodnich tradycjami mieszczańskiego liberalizmu. W ten sposób okoliczności wynikające z uwarunkowań długiego trwania konfrontowanego z kolejnymi przekształceniami tworzyły szczególne rozwiązania na obszarze Niemiec Wschodnich (Ostebien), różniące się zarówno od rzeczywistości zachodnioniemieckiej, jak i środkowoeuropejskich krajów słowiańskich. Cechy te odziedziczył i dalej przekształcał system Niemieckiej Republiki Demokratycznej, tworząc kolejną odsłonę wschodnioniemieckiej szczególnej drogi i ugruntowując w nawiązaniu do tych cech tożsamość wschodnioniemiecką. Nie byłaby więc ona tylko wypadkową istnienia wschodnioniemieckiej odrębności politycznej i społeczno-gospodarczej z lat 1945-1990, ale również wcześniejszych cech charakteryzujących kolejne stadia rozwojowe.

Wpływu 45-letniego okresu funkcjonowania systemu socjalistycznego na formowanie się odrębności dzisiejszego społeczeństwa wschodnioniemieckiego nie sposób zanegować. Wiąże się on z konkretnymi wartościami, ideami i symbolami oraz społecznymi i infrastrukturalnymi rozwiązaniami. Wobec przytoczonych powyżej spostrzeżeń nie można jednak odrzucić znaczenia wcześniejszych 
uwarunkowań na kształtowanie się dzisiejszych cech społeczeństwa wschodnioniemieckiego. Należy rozważyć możliwość, że kształtowana od wieków odrębność niemieckiego Wschodu (Slavia Germanica, Ostelbien) mogła mieć znaczącą rolę w formowaniu się szczególnego oblicza wschodnioniemieckiego systemu socjalistycznego, a później społecznej odrębności landów wschodnich. Na pewno zaś połączenie wcześniejszych uwarunkowań z rozwiązaniami wprowadzanymi przez komunistów musiało dodatkowo wzmocnić odrębne cechy niemieckiego Wschodu względem regionów zachodnioniemieckich, które przecież nie doświadczały ani jednych, ani drugich uwarunkowań. Koncepcja długiego trwania wydaje się w tym kontekście użytecznym kierunkiem wyjaśniania obserwowanych zjawisk i procesów.

\section{Literatura}

Berger D., 1999, Geographische Namen in Deutschland, Duden, Mannheim.

Braudel F., 1982, On History, University of Chicago Press, Chicago.

Breza E., 1987 (1988), Wybrane nazwiska mieszkańców pótnocnych Kaszub, „Gdańskie Studia Językoznawcze", 4: 83-129.

Bundestagswahl 2017, https://www.bundeswahlleiter.de/bundestagswahlen/2017/ergebnisse.html (dostęp: 10.02.2021).

Cetwiński M., 2001, Ślaski tygiel: studia z dziejów polskiego średniowiecza, Wydawnictwo Wyższej Szkoły Pedagogicznej w Częstochowie, Częstochowa.

Czechowicz B., 2007, Sukcesorzy ślaskich Piastów. W trzechsetlecie śmierci ostatniej z rodu (1707-2007), Oficyna Wydawnicza Atut, Wrocław.

Dołowy-Rybińska N., 2011, Języki i kultury mniejszościowe w Europie. Bretończycy, Eużyczanie, Kaszubi, Wydawnictwo Uniwersytetu Warszawskiego, Warszawa.

Eddie S.M., 2008, Landownership in Eastern Germany before the Great War: A quantitative analysis, Oxford University Press, Oxford-New York.

Filip M., 2012, Od Kaszubów do Niemców: Tożsamość Stowińców z perspektywy antropologii historii, Nauka i Innowacje, Poznań.

Fukuyama F., 2012, Historia ładu politycznego, t. 1: Od czasów przedludzkich do rewolucji francuskiej, Dom Wydawniczy Rebis, Poznan.

Gawlas S., 2000, O ksztalt zjednoczonego królestwa: niemieckie władztwo terytorialne a geneza spoleczno-ustrojowej odrębności Polski, DiG, Warszawa.

Hardt M., 1999, Das slawische Dorf und seine kolonisationszeitliche Umformung nach schriftlichen und historisch-geographischen Quellen. Siedlungsforschung, „Archäologie-Geschichte-Geographie", 17: 269-291.

Hawes J., 2018, The shortest history of Germany, Old Street Publishing, London.

Hay M., 2021, Famous people's Y-DNA listed by haplogroup, https://www.eupedia.com/ genetics/famous_y-dna_by_haplogroup.shtml (dostęp: 10.02.2021). 
Immel D.-U., Krawczak M., Udolph J., Richter A., Rodig H., Kleiber M., Klintschar M., 2006, Y-chromosomal STR haplotype analysis reveals surname-associated strata in the East-German population, „European Journal of Human Genetics”, 14: 577-582.

Janczak J., Ładogórski T. (red.), 1976, Śląsk w końcu XVIII wieku, t. 1, cz. 2, Atlas Historyczny Polski. Mapy XVIII wieku, 1, Ossolineum, Wrocław.

Jiménez F., 2015, So sieht es in der Psyche von Ossi und Wessi aus, „Die Welt”, https:// www.welt.de/gesundheit/psychologie/article147131006/So-sieht-es-in-der-Psyche-von-Ossi-und-Wessi-aus.html (dostęp: 10.02.2021).

Jurek W., 1975, Rozwój gospodarczy Niemieckiej Republiki Demokratycznej w jej dwudziestopięcioleciu, „Ruch Prawniczy, Ekonomiczny i Socjologiczny”, 3: 65-79.

Jurkat K.-P, 2005, Neue Beiträge zur Baltistik, Bergisch Gladbach: R\& R Printservice, http://prussia.online/books/neue-beitraege-zur-baltistik (dostęp: 10.02.2021).

Kaczmarczyk Z., 1953, Rozprzestrzenienie się narodowości polskiej nad Odrą i Battykiem w późnym feudalizmie, „Przegląd Zachodni”, 9: 9-30.

Kirsch K., 2004, Slawen und Deutsche in der Uckermark: vergleichende Untersuchungen zur Siedlungsentwicklung vom 11. bis zum 14. Jahrhundert, Franz Steiner Verlag, Stuttgart.

Klec-Pilewski B., 1991, Studia i przyczynki do historii, genealogii i heraldyki polskiej, Londyn.

Kleiner Atlas der Siedlungsnamen Deutschlands, http://deutschlandkarten.nationalatlas. de/ (dostęp: 10.02.2021).

Kleßmann Ch., 2014, Niemiecki Wschód, [w:] Kleßmann Ch. (red.), Niemiecki Wschód: wyobrażenia - misja - dziedzictwo, Wydawnictwo Nauka i Innowacje, Poznań: 7-40.

Kokot J., 1973, Problemy narodowościowe na Śląsku od X do XX wieku, Wydawnictwo Instytutu Śląskiego w Opolu, Opole.

Komossa G.-H., 2006, Z Mazur nad Ren. Powrót na obczyznę, Libron, Kraków.

Kornelius S., 2014, Angela Merkel, Alma Books, Surrey.

Kortus B., 2004, Rola geografii w polskiej myśli zachodniej XX wieku, „Przegląd Zachodni”, 60(2): 105-130.

Kossert A., 2004, Mazury. Zapomniane potudnie Prus Wschodnich, Wydawnictwo Scholar, Warszawa.

Kowalski M., 2013, Przedsionek Europy. Miejsce Polski w systemie geopolitycznym nowożytnej Europy, [w:] Eberhardt P. (red.), Studia nad geopolityka XX wieku, IGiPZ PAN, Warszawa: 235-263.

Kowalski M., 2020, The Early Mediaeval Slav-German border (Limes Sorabicus) in the light of research into Y-chromosome polymorphism in contemporary and historical German populations, „Geographia Polonica”, 93(4): 569-596.

Kowalski M., Śleszyński P., 2010, Migracje Polaków do Niemiec w świetle częstotliwości występowania najbardziej popularnych polskich nazwisk, „Przegląd Zachodni”, 66(2): 115-130. 
Kruse W., 1929, Die Deutschen und ihre Nachbarvölker. Neue Grundlegung der Anthropologie, Rassen-, Völker-, Stammeskunde und Konstitutionslehre nebst Ausführungen zur deutschen Rassenhygiene, Thieme, Leipzig.

Kucharczyk G., 2020, Prusy. Pięć wieków, Wydawnictwo Bellona, Warszawa.

Laschewski L., 1998, Continuity and change-agricultural restructuring in East Germany, „Eastern European Countryside”: 37-48.

Lippert R., 2001, Das Fürstenhaus von Mecklenburg-Strelitz, [w:] Erstling F., Saß F., Schulze E. (red.), Mecklenburg-Strelitz, Beiträge zur Geschichte einer Region, Friedland: 171-191.

Lübke Ch., 2014, Von der ,Sclavinia 'zur Germania Slavica: Akkulturation und Transformation, [w:] Härtel R. (red.), Vorträge und Forschungen, 78: Akkulturation im Mittelalter, Jan Thorbecke Verlag, Ostfildern: 207-234.

Mally A.K., 1974, „Piefke”. Herkunft und Rolle eines österreichischen Spitznamens für den Preußen, den Nord- und den Reichsdeutschen, [w:] „,Muttersprache. Zeitschrift zur Pflege und Erforschung der deutschen Sprache", 84(4): 257-286.

Mączak A., 1998, Feudalizm w pierwszej Rzeczpospolitej. Wieloznacznosć terminu i ewolucja zjawiska, [w:] Manikowska H., Kochanowicz J. (red.), Feudalizm w Europie średniowiecznej i nowożytnej, „Roczniki Dziejów Społecznych i Gospodarczych”, 58: 177-185, Wydawnictwo: Poznańskie Towarzystwo Przyjaciół Nauk, Poznań.

Muka K.A., 1904, Szczątki języka połabskiego Wendów Luneburskich, Materiały i Prace Komisyi Językowej Akademii Umiejętności w Krakowie, t. I: 313-569, Kraków.

Mühle E., 2020, Stowianie. Rzeczywistość i fikcja wspólnoty. VI-XV wiek, Wydawnictwo Naukowe PWN, Warszawa.

North M., 2015, Geschichte Mecklenburg-Vorpommerns, C.H. Beck, München.

Orzechowski K., 1957, Własność feudalna i jej przemiany u schyłku epoki: (głównie na tle stosunków Europy środkowej i ze szczególnym uwzględnieniem Śląska), „Czasopismo Prawno-Historyczne", 9(2): 77-150.

Piskorski J.M., 2005, Kolonizacja wiejska Pomorza Zachodniego w XIII $i$ w poczatkach $X I V$ wieku na tle procesów osadniczych w średniowiecznej Europie, Wydawnictwo: Poznańskie Towarzystwo Przyjaciół Nauk, Poznań.

Pol W., 1989, Na lodach; Na wyspie; Na groblach: trzy obrazki znad Battyku, Wydawnictwo Morskie, Gdańsk.

Reif H., 1994, Ostelbische Agrargesellschaft im Kaiserreich und in der Weimarer Republik: Agrarkrise-junkerliche Interessenpolitik-Modernisierungsstrategien, Akademieverlag, Berlin.

Rudnicki M., 1936, Nadolny Rudolf. Germanísierung oder Slavisierung, [w:] „Slavia Occidentalis", 15: 211-250.

Rymar E., 2005, Rodowód książąt pomorskich, Książnica Pomorska im. Stanisława Staszica, Szczecin.

Schich W., Stephan J., 2015, Strukturalne przemiany na Ślasku wywołane akcja kolonizacyjna na przyktadzie biskupiego księstwa nyskiego, „Studia Geohistorica”, 3: 205-218. 
Schmilewski U., 2001, Der schlesische Adel bis zum Ende des 13. Jahrhunderts. Herkunft, Zusammensetzung und politisch-gesellschaftliche Rolle, Würzburg.

Schoebel M., 2003, Putbus, Wilhelm Malte Fürst, „Neue Deutsche Biographie (NDB)”, 21: 16-18, Duncker \& Humblot, Berlin.

Schröder V., 2020, Wahlen in Deutschland, https://www.wahlen-in-deutschland.de/index. html (dostęp: 10.02.2021).

Schulze H., 2012, Państwo i naród w dziejach Europy, Wydawnictwo Uniwersytetu Warszawskiego, Warszawa.

Siatkowski J., 2015, Historia badań nad wpływami słowiańskimi na język niemiecki, „Gwary Dziś”, 7: 141-154.

Skóra W., 2004, Kaszubi bytowscy i lęborscy w świetle opracowania urzędnika MSZ II Rzeczypospolitej z 1930 roku, „Acta Cassubiana”, 4: 295-336.

Srokowski S., 1937, Ludność Prus Wschodnich, Bellona, Warszawa.

Stöpel Ch., 2005, Geogen Deutschland 3.2 Online, https://legacy.stoepel.net/de/ (dostęp: 10.02.2021).

Strzelczyk J., 1974, Słowianie na południowym Pogórzu Harzu i na Złotej Niwie, „Przegląd Historyczny”, 65(2): 223-242.

Strzelczyk J., 1976, Stowianie koło Erfurtu, „Slavia Antiqua”, 23: 211-228.

Szczepankiewicz-Battek J., 2005, Łużyce-przestrzeń dysocjacji kultur narodowych i religijnych, Pomorska Akademia Pedagogiczna w Słupsku, Słupsk.

Szczepański M.S., 1999, Tożsamość regionalna - w kręgu pojęć podstawowych i metodologii badań. Między tożsamościa indywidualna a społeczna - preliminaria (maszynopis), http://www.socjologiarozwoju.us.edu.pl/documents/25.html (dostęp: 10.02.2021).

Szücs J., 1995, Trzy Europy, Instytut Europy Środkowo-Wschodniej, Lublin.

Šołta J., 1984, Zarys dziejów Serbołużyczan, Zakład Narodowy im. Ossolińskich, Wrocław.

Teztner F., 1902, Die Slawen in Deutschland, F. Vieweg und Sohn, Braunschweig.

Thalheim K.C., Ziegfeld A.H., 1936, Der deutsche Osten. Seine Geschichte, sein Wesen und seine Aufgab, Propyläen, Berlin.

Thies J., 2012, Die Moltkes: Biographie einer Familie, München.

von Manstein E., 1958, Aus einem Soldatenleben. 1887-1939, Athenäum-Verlag, Bonn.

von Wedel J., 2011, „Landarbeiterenquete” Maxa Webera a transformacja z roku 1990, „Przegląd Zachodniopomorski”, 26(3): 165-177.

Wagner P., 2005, Bauern, Junker und Beamte. Lokale Herrschaft und Partizipation im Ostelbien des 19. Jahrhunderts, Wallstein, Göttingen.

Wawrykowa M., 1976, Dzieje Niemiec 1648-1789, Państwowe Wydawnictwo Naukowe, Warszawa.

Weber M., 1993, Entwicklungstendenzen in der Lage der ostelbischen Landarbeiter (1894), [w:] Weber M. (red.), Gesamtausgabe, I, 4(1): 362-462, Mohr Siebeck, Tübingen. 
Wittich W., 1892, Gutsherrschaft (Grundherrschaft, Leibeigenschaft, Eigenbehörigkeit und Erbunterthänigkeit), „Handwörterbuch der Staatswissenschaften”, 4: 229-236.

Zabrocki L., 1961, Transpozycje strukturalne prusko-polsko-niemieckie w zakresie nazw topograficznych Pomorza Mazowieckiego, [w:] Taszycki W. (red.), I Międzynarodowa Slawistyczna Konferencja Onomastyczna $w$ Krakowie $w$ dniach 22-24 października 1959. Księga referatów, Państwowe Wydawnictwo Naukowe, Wrocław-Warszawa-Kraków: 201-232.

Zernack K., 2014, Pojęcie historyczne „Niemcy Wschodnie” a niemiecka Landesgeschichte, [w:] Kleßmann Ch. (red.), ,Niemiecki Wschód : wyobrażenia-misja-dziedzictwo, Wydawnictwo Nauka i Innowacje, Poznań: 65-86.

\title{
The distinctiveness of East Germany in the light of the concept of longue durée
}

\begin{abstract}
The reunification of Germany in 1990 revealed a clear difference between the two parts of the country. This is visible, for example, in the political sympathies revealed during the elections. These differences are most often explained by the 45-year period of the country's division and the functioning of two different political and socio-economic systems. Nevertheless, the differences between the East and West of Germany were noticed even before 1945. The East later became part of Germany and was initially inhabited by Slavic peoples. The local German society was created by mixing the settlers from the west with the local Slavic people. The relics of this process are linguistic differences (toponymy, anthroponymy, borrowings in local dialects) that persist to this day, as well as different features revealed in genetic research. As a result of the interaction between local conditions and ideas flowing from the West, a completely new settlement, economic and legal system was also created. It can be assumed that the emergence of these conditions also influenced the later development of the socio-economic and political system in this area. Large unified principalities (Brandenburg, Saxony, Pomerania, Mecklenburg, Prussia) were established in the east, so there was no room for political and systemic pluralism as in the west (free cities, free nobility of the Reich). The local princes gained a dominant position, basing their power on subordinated vassal nobility. There was a weakness of the cities and the bourgeoisie. In these conditions, in the process of the so-called secondary feudalization, formed the separateness of the so-called Ostelbien, associated with the dominant role of the nobility and the manorial serf economy. The liquidation of the feudal system also took a specific form here due to the so-called the Prussian road to capitalism in agriculture. It maintained the privileged position of the nobility (Junkers) in the socio-economic and political life of East Germany. Initially, autocracy was associated with conservative tendencies. Later, above-average sympathies for left-wing movements developed here. The conservatism of the nobility and the rich peasantry coexisted with the leftism of a large number of hired workers in agriculture. The influence of the authoritarian socialist system overlapped with these earlier conditions, partially in harmony with them, further strengthening the separateness of East Germany from the West.
\end{abstract}


Keywords: Slavia Germanica, Ostelbien, East Germany, longue durée.

Dr hab. Mariusz Kowalski, prof. IGiPZ

Polska Akademia Nauk

Instytut Geografii i Przestrzennego Zagospodarowania

Zakład Przestrzennego Zagospodarowania

e-mail:mar.kow@twarda.pan.pl

(iD) https://orcid.org/0000-0003-3417-0369 